\title{
CIRCULAR ECONOMY IN CHILE: BACKGROUND, LAW AND OPPORTUNITIES
}

\author{
VALERIA SCAPINI $^{1} \&$ PRISCILLA BERRIOS ${ }^{2}$ \\ ${ }^{1}$ Centro de Investigación en Innovación, Desarrollo Económico y Políticas Sociales (CIDEP), \\ Universidad de Valparaíso, Chile \\ ${ }^{2}$ Universidad de Valparaíso, Chile
}

\begin{abstract}
Motivated by the fact that Chile is the largest generator of waste (per person, per day) in South America, and at the same time, it belongs to the region of the world with the lowest rates of recycling, the purpose of this study is to understand the problem that the current linear economy approach brings with it, understand the circular economy approach and the importance of adopting this approach as soon as possible as it can be sustained in the long term. The particular case of Chile is interesting as it is a country that is largely financed by the extraction and export of its natural resources such as copper. The economy needs to be diversified and its dependence on raw materials reduced in order to strengthen other economic sectors. On the other hand, waste management is a major challenge since it is recycled less than the world average and even less than the regional average. Specifically, this publication describes the current situation of the country regarding the circular economy, the state of progress of the respective Chilean legislation and the main courses of action. We also exhibit some examples of successful national companies that have adopted this approach. Finally, the main challenges and opportunities that this paradigm shift presents to consumers and producers are pointed out.
\end{abstract}

Keywords: circular economy, consumer behaviour, waste, recycle, legislation, business strategy.

\section{INTRODUCTION}

The economic history of Chile shows the importance that natural resources have had in our economy because we have always been an extractor and exporter of raw materials, mostly minerals [1]. The arrival of Spanish conquerors to our land was driven by the search for gold and silver; however, our relative poverty compared to other countries of the region such as Mexico and Perú, consolidated the exploitation of gold panning activities which permitted the financing of the beginning of colonization in the 16th century. The mining activity was consolidated in the north of the country and organized around three traditional metals: gold, silver and copper. During the 17th century the export of copper to Perú began for the manufacture of cannons, and subsequently during the 18th century, the exploitation of gold and silver acquired relevance and generated an important income for the government. In the 19th century, copper mining used a rudimentary and labor intensive technology, but the investment of large North American companies installed in the country allowed Chile to position itself as the world's leading copper exporter $(16.7 \%$ of the worldwide production) [1]-[3].

On the other hand, it is important to mention the history of saltpeter in our country, known as "white gold" that began its exploitation in 1830 and lasted 100 years. Saltpeter began to be used in Europe for the manufacture of explosives and the creation of fertilizers. Saltpeter abundance and quality boosted the national industry leading Chile quickly to position itself as the largest exporter worldwide. At the beginning of the 20th century, saltpeter exports reached a 75\% share of the country's exports. Even though exploitation was in private hands, a high export tax was applied that allowed the government to retain a large amount of resources for the economy, reaching a relative participation higher than 
50\%. Lastly, the Great Depression of 1929 brought consequences to the saltpeter industry, forcing the country to reorganize the industry [1], [2].

Currently, mining activity represents just the $10 \%$ of GDP, however, copper alone constitutes $50 \%$ of our country's exports. Fig. 1 shows us the relative importance of copper in the country's total exports during the last 15 years. The rest of the exports are mainly made up for the sale of agricultural products, manufacturing (food, wood, pulp and paper, oil refining, chemicals, non-metallic minerals, metallic products), fishing and aquaculture, forest and minerals and wine [4]. This shows us that we continue to be a country that is mainly an exporter of natural resources, showing us therefore, with the understanding that many of these resources are finite, that our economy cannot be sustained in the long term. Chile has the largest copper reserves in the world with approximately 200 million metric tons [5] and, considering that the country's annual copper production is around 6 million tons [6], our reserves will run out in a period of approximately 30 years. This obligates us to decouple our economic development from the consumption of finite resources, that is, to adopt a circular economy approach.

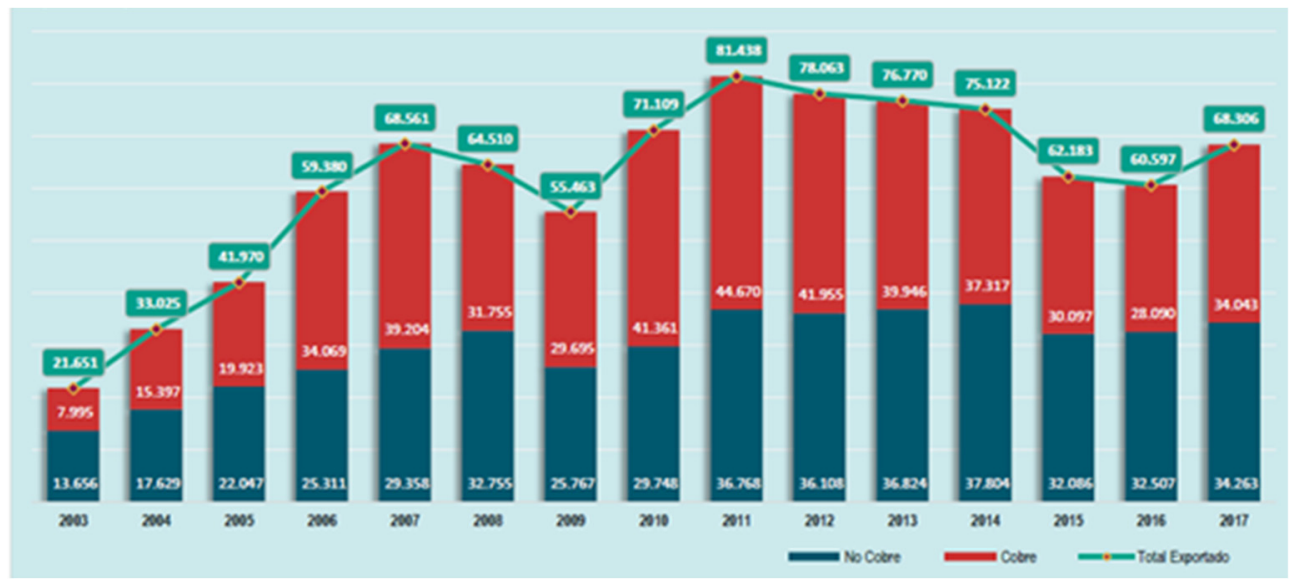

Figure 1: Chilean total exports (2003-2017) (US\$ millions) [4].

The purpose of this study is to understand the problem that the current linear economy approach brings with it, to understand the circular economy approach and the importance of adopting this approach as soon as possible as it can be sustained in the long term. Additionally, to understand the state of progress of this approach in Chile.

The present document is structured as follows. Section 2 provides a literature review on the importance of the circular economy, Section 3 the methodology; Section 4 shows the result of the investigation that describes the Chilean legislation in this regard, as well as some successful examples and opportunities we have as a country. Finally, the conclusion is presented in Section 5.

\section{LITERATURE REVIEW}

The term circular economy was used for the first time by the British environmental economists David Pearce and Kerry Turner in 1990 in their book Economics of Natural Resources and the Environment, where they mentioned that the materials of an economy flow in a closed circle [7]. Subsequently, the concept was implemented in Germany in 1996 
and then in Japan in 2002 as part of a policy of environmental legislation in waste management, while in China this concept was adopted as a new model for sustainable economic development more than just an environmental policy [8]. In 2010 Ellen MacArthur created the foundation that was named after her with the goal of accelerating the transition towards a circular economy model and for this she works in conjunction with governments, companies and universities [9].

Circular economy is based on the concept of "return and renew" and appears to do away with the culture of linear economy characterized by "throw away and replace" that has operated in the last 200 years, started principally after the industrial revolution and is characterized by generating products through the exploitation of finite resources which, after a period of use, are discarded (resource-product-residue). On the contrary, the circular economy is focused on the efficient use of resources and energy, looking at the productive process more than at their final result. This approach involves topics related to the redesign of products, their components and the use of packaging with biodegradable and safe materials. The most important part of this concept is to re-examine and reorient both the sources of resources and their (re) use to prevent the product from being discarded, and thereby achieve the use of products and materials for the maximum time possible. In this way, this approach seeks the decoupling of economic growth and development from the consumption of finite resources [9].

Worldwide, the indiscriminate extraction and consumption of resources has brought into question the idea of sustainability in the last 50 years [10], [11] emphasizing the importance of the adoption of this new focus for everyone, not just for countries that export raw materials. In the same way, the United Nations has put into discussion the concept of sustainable development with his objectives (SDG). On the other hand, pollution is also a problem that worries us all, generates health problems such as respiratory complications, major risk of cardiovascular diseases and decreases the quality of life and generates environmental effects like droughts, disappearance of species and global warming [12]. Given the above, our production process has to move towards one that uses clean and renewable energy. Here we have a tremendous challenge in creating or advancing these types of energy solutions. Our products have to change as well. We have to think about redesigning products, their components and the packaging in which they are sold and using safe and biodegradable materials. As consumers we have to strive for a responsible consumption and take care of our waste [9].

\subsection{Garbage and waste}

Planet earth has existed for approximately 4.6 billion years and life for about 3.8 billion years. From the first forms of life until the arrival of man, garbage did not exist because species ate each other, and all waste was in turn a nutrient for the earth or food for others. However, since the arrival of man, garbage has existed, and it is $100 \%$ human [9].

The difference between garbage and waste consists in that, on the one hand, garbage is all of what cannot be used again nor recycled in any way; on the other hand, waste is everything that, although it has been used, can still be recycled, for example: glass, paper, aluminium, recycle plastic [13]. Currently not enough is recycled and therefore our dumps or landfills are full of garbage and waste. In the world, an average $0.74 \mathrm{~kg}$ of garbage is generated per day per person, in Latin America the average is $0.87 \mathrm{~kg}$ per day per person. In Chile, a quantity greater than the world and regional average is generated, that is, $1.26 \mathrm{~kg}$ of garbage are produced per day per person. We are the country that generates the most garbage in Latin America on a per capita basis. On the other hand, we recycle only $4 \%$ of 
what we generate, a number below the regional average of $4.5 \%$ and far below the world average of $13.5 \%$ [14].

The garbage produced mainly ends up in landfills. In Chile there are a total of 38 landfills located throughout the country. On occasion, the garbage generated is placed in illegal dumps which are located in peripheral and lower income areas, negatively affecting these places because they must allocate resources to eliminate waste and garbage [15].

\section{METHODOLOGY}

The methodology used is based on a literature review. Firstly, background information was compiled on Chile's economic history and its strong dependence on resource extraction. Subsequently, information was gathered on the importance of the circular economy approach and the difference between it and the traditional linear economy approach. Both points were presented in the previous sections. Then, a bibliographic review of Chilean legislation related to the circular economy and its state of progress was carried out. Next, some examples of companies that have currently adopted this approach were identified. Finally, some opportunities and challenges for the country were listed.

\section{RESULTS}

\subsection{Legislation in Chile}

Chile has had a Ministry of Environment since 2010. This ministry has a Circular Economy office, the first in Latin America, whose lines of work are the following [16]:

(a) Implementation of an Extended Producer Responsibility Law (Ley REP)

(b) Recycling Fund

(c) Circular Economy Roadmap

(d) Grassroot Recyclers Inclusion Policy

(e) Action Plan against Plastic Pollution

(f) Organic Waste Management Strategy

(g) Construction and Demolition Waste (RCD)

(h) Cross-Border Waste Movement

One of the main areas of action considered by the Ministry in order to move towards a circular economy model in the country is related to the implementation of the Extended Producer Responsibility Law (REP). This law seeks to decrease the generation of waste and promote its reuse, recycling and other types of valuation. The main functions carried out include the implementation of programs, plans, policies and regulations to reduce and control the generation of waste, for the circular economy, and for eco-labeling. Likewise, it participates in collaborative actions between the Ministry and competent organizations for the formulation of environmental policies, as well as collaboration in the proposal of actions for citizen participation in the formulation of policies [16]. The REP Law created a recycling fund that is managed by the Circular Economy office, and finances projects aimed at preventing the generation of waste at the community level and promoting their separation, reuse and recycling [16].

In December 2020, a public consultation process on the "Circular Economy Roadmap 2020-2040" was initiated, the goal of which was to increase the current level of recycling from $4 \%$ to $65 \%$ in 2040 [17]. Since 2018, collaborative work has been done between the private sector, public sector, civil society and academia to determine the main participants 
and sectors. The proposal prepared has 32 initiatives with 92 actions in four courses of action: circular innovation, circular culture, circular territories and circular regulation [16].

In relationship to the Grassroots Recyclers Inclusion Policy, initiated in august 2016 to promote the inclusion of grassroots recyclers in waste management, three strategic guidelines were considered: environmental, economic and social, and each of them with specific objectives. The initial action plan considered activities that were carried out in the period of 2016-2020 and are currently reformulated for the 2020-2021 period [16].

Continuing with the Action Plan against Plastics Pollution, a labeling system is being developed that indicates the recyclability of the containers and packing of the products [16]. Its desired effect is the promotion of the recycling culture by providing information to consumers. This is a pilot phase project to collect information in order to continue with a larger scale outreach phase incorporating aspects of improvement.

In relation to the management of organic waste, the Ministry of the Environment has a National Strategy for Organic Waste that, during 2020, was under public consultation. The idea of this strategy is to advance from less than $1 \%$ current reuse to an overall goal of $66 \%$ in 20 years.

In August 2020, the "RCD Roadmap Circular Economy in Construction 2035" was launched and its implementation started. Construction activities create a great demand for raw materials and are a great generator of waste $35 \%$ of waste globally comes from construction). This roadmap is a multisectoral initiative that was developed between the Ministries of the Environment, Public Works and Housing that seeks to encourage and promote sustainable waste management under the Circular Economy approach [16].

The last action line of the Ministry is moving forward to achieve the Basel Convention that is related to the "Control of transboundary movements of Hazardous Waste and its Elimination".

Lastly, in relation to the main laws that are currently in force and that have allowed progress in the generation of waste and/or in promoting a Circular Economy approach, the following can be mentioned:

(a) Law $\mathrm{N}^{\circ}$ 20879: In 2015 the Ministry of Transport and Telecommunications promulgated "Law 20,879" that sanctions the transportation of waste to illegal dumps [18].

(b) Law N $\mathrm{N}^{\mathrm{2}} 21100$ : In 2018 the Ministry of the Environment promulgate "Law 21100" that prohibits the delivery of plastic bags in all the national territory, thus prohibiting the delivery of plastic bags in supermarkets and in commerce in general [19]. The fight against plastic has not yet finished, there is currently a project in the Chamber of Deputies to eliminate single-use plastics such as food containers, plates, glasses and silverware.

(c) Law N $\mathrm{N}^{\circ}$ 20920: This law set a framework for waste management, that extends producer responsibility and promotion of recycling. It is known as the REP Law and was promulgated in 2016 by the Ministry of the Environment. It establishes that the producer of "priority products" must take responsibility for the products they sell and their recovery at the end of life to prevent them from becoming waste. The "priority products" are: tires, containers and packaging, batteries, lubricating oils and electrical and electronic equipment [20].

\subsection{Some examples}

In Chile, more companies are everyday joining the commitment to the environment, adhering to the clean production agreement and subjecting their packaging to a certification 
process so that their products have an ecological label that identifies them as recyclable packaging. On the other hand, companies are driving important changes by adopting a circular economy approach. Some successful worldwide examples are the following.

\subsubsection{Algramo}

Algramo is a company whose purpose is to transform the habit of consumption to save the planet. They distribute products of basic necessities in bulk in neighborhood warehouses, with dispensing machines and in reusable containers, that allows a reduction in the sales price. Another line of business corresponds to the sale of products in reusable packing, which completely eliminates the packing of the products and allows a reduction in the sales price [21] (Fig. 2).

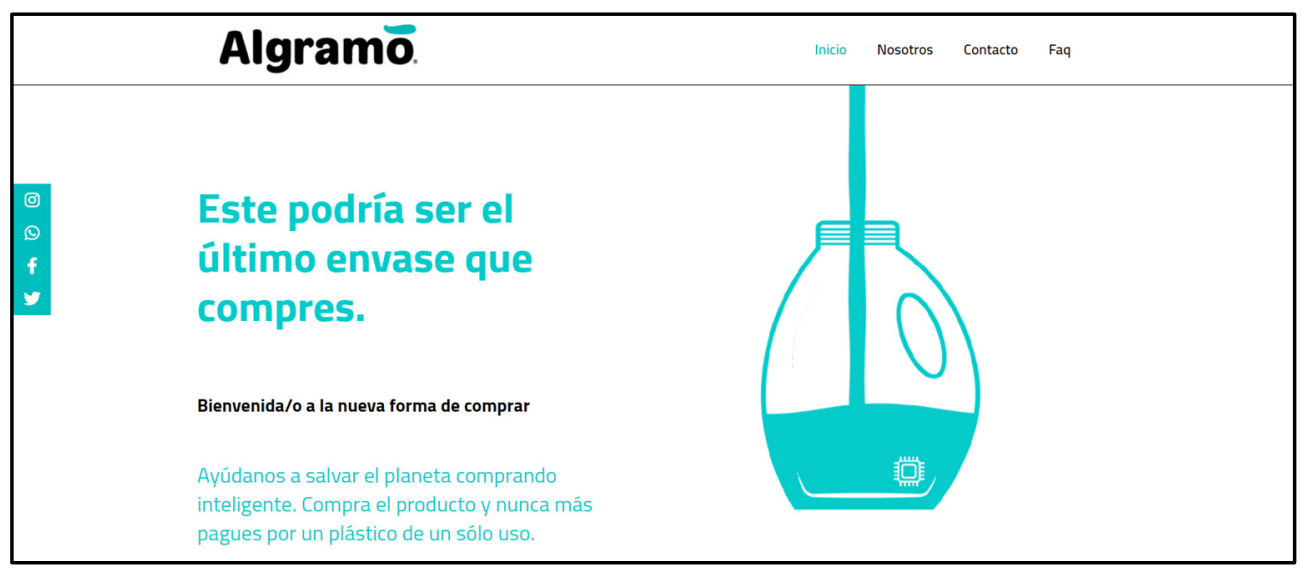

Figure 2: Algramo seeks to generate a radical change in consumption habits [21].

\subsubsection{Green glass}

Green Glass is a company that manufactures glasses from bottles recovered from garbage and bought directly from grassroots collectors. In Chile, at least 1.4 million glass bottles are thrown away in the garbage every day, therefore, the company contributes to the reuse of this waste and additionally contributes to job creation [22] (Fig. 3).

\subsubsection{Cambiaso hermanos}

Cambiaso is a family business dedicated to tea that, since the $1980 \mathrm{~s}$, ventured into the plastic area for packaging its own products. Over time, plastics have transformed into a business unit and they specialize in the production of cleaning bags and packaging products in general. The bags are made with recycled plastic and are biodegradable within 2 years [23] (Fig. 4).

\subsection{Opportunities}

Adopting a Circular Economy approach creates a series of opportunities, which are described below. First, as a country we could decouple economic development from the consumption of finite resources, which will allow us to diversify our productive matrix and hedge against future price volatilities. In this sense, a joint effort of the entire society is 


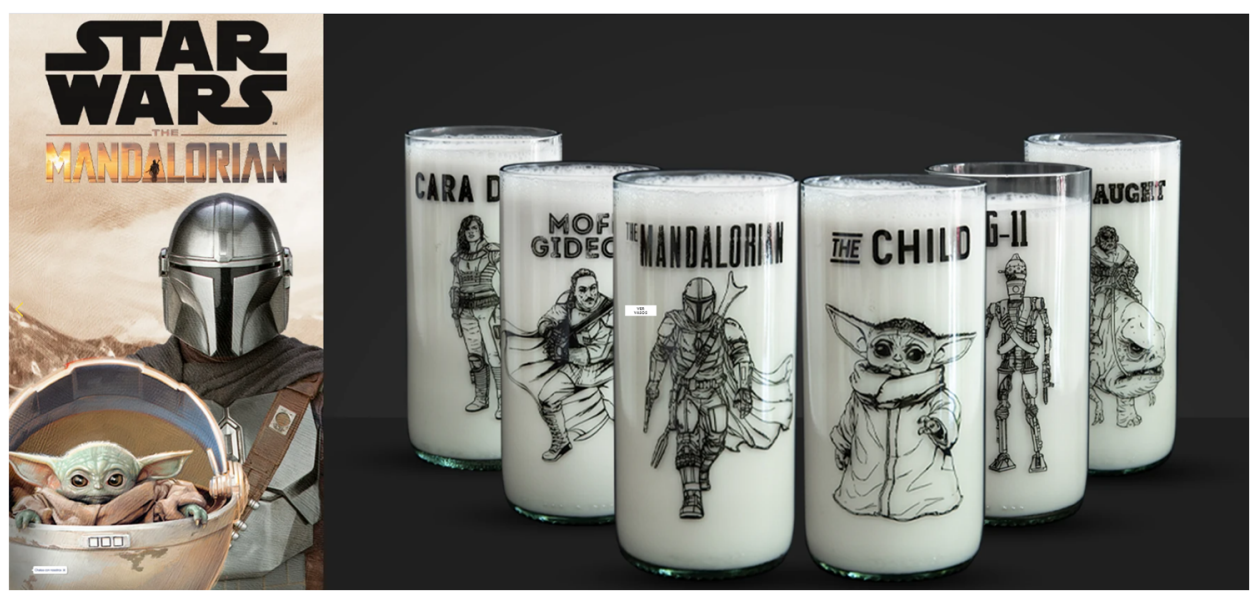

Figure 3: Example of thematic glasses that Green Glass sells [22].

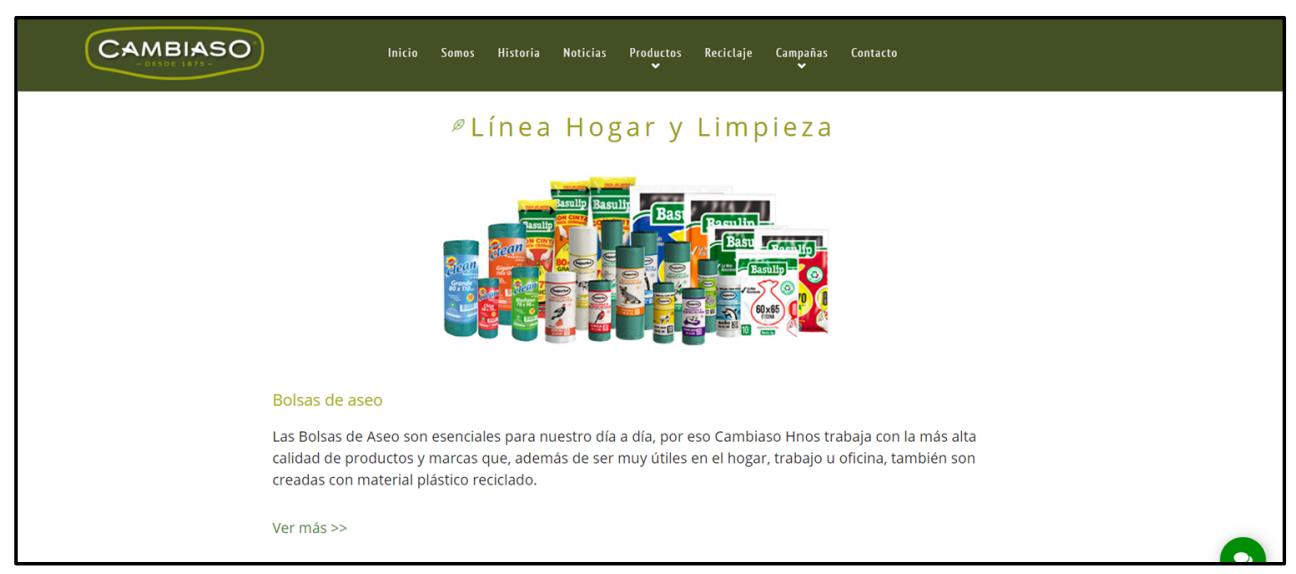

Figure 4: Example of bags that Cambiosa sells [23].

required to achieve public knowledge of the circular economy concept. In this way, educational entities are key actors in environmental education, research and knowledge transfer aimed at training responsible citizens. At the same time, non-governmental entities play an important role in raising awareness of this concept.

In parallel, there is a great opportunity for companies to adopt this approach. Some of the benefits that are generated are tangible benefits such as profits and savings, and others are intangibles such as recognition, reputation, innovation and collaboration [24]. Additionally, the adoption of this model is directly related to the generation of new jobs. To achieve a circular economy, companies must improve the sustainable productive capacity of the industry, where innovation is a fundamental element. Producers must rethink and redesign their products, components and the packaging in which the final product is sold, working with safe and biodegradable materials during the entire process and collaboration between companies [9]. 
There are materials that are considered good for circular economy because they can be transformed into raw materials, from waste to resource, some of these are:

(a) Glass: Selected, clean and ground glass allows the manufacture of glass containers exactly the same as the original ones. The manufacturing process of these recycled containers consumes less energy than the original one.

(b) Industrial oil: Used industrial oil is one of the most dangerous wastes that exists. They can be fully exploited for the manufacture of new products or as an alternative energy source

(c) Tires: Used tires, which can take more than a thousand years to disappear, form granulate for infills and as the basis for artificial grass fields and safety floors in playgrounds, as well as for the "recycled highways" of the future, silent and durable.

(d) Plastic: Plastic is a highly recyclable material.

(e) Cork: Is a natural, recyclable and renewable product. The bottle stoppers collected are crushed and the granules obtained are used to make cork products not intended for food, such as materials for construction or for the creation of objects for domestic and artistic use, following the tendency of eco-design.

(f) Aluminium: Material that can be recycled indefinitely and saves up to $95 \%$ of the energy needed to produce it from ore. Regarding the saving of polluting emissions, production processes using recycled aluminium generate only $15 \%$ of the emissions with respect to an aluminium production based on the mineral from which it comes, bauxite.

Lastly, adopting this approach allows us to transform our consumption habits. There are more and more consumers that are becoming aware of the environment and deciding to buy ecological products that do not pollute and are respectful with the environment. This transformation considers the reflection on our consumption habits and the decisions adopted when buying. In addition, the consumer internalizes the habits of separating waste (as part of the process of its preparation for recycling) and its recycling. In the particular case of organic waste, consumers begin to consider learning and implementing composting, thus preventing garbage and waste from reaching landfills.

\section{CONCLUSIONS}

Natural resources have always been the basis of the Chilean economy, and currently copper represents $50 \%$ of exports. Given this relevance for the country and considering that many resources are depleted, it is necessary to diversify our economy and reduce its dependence on the export of raw materials. In this way, other economic sectors can be strengthened as well as the environmental impacts related to the resource extraction can be reduced. This, added to the environmental problems that we are currently experiencing in the world, indicates the need to transit towards a circular economy approach in which we make the best use of the planet's resources while working to avoid the generation of waste. Let us remember that this concept must consider raw materials, the process and the product, so it goes beyond the simple task of waste management, since it consists of a radical transformation in production methods and in consumption habits.

In Latin America, and particularly in Chile, waste management presents a large gap in relation to the average world, where most organic waste is not composted, and still large amounts of waste are not recycled, ending in landfills or dumps, making waste management a great challenge for the country.

In Chile, in the last 10 years, legislation has advanced to reduce the environmental impact related to waste generation and promote the Circular Economy model. Currently the 
two main lines of work are, first, the implementation of Law $N^{\circ} 20,929$ (REP) that establishes the framework for waste management, extended producer responsibility and promotion of recycling, and second, advancing in a regulatory framework and other instruments that allow us to transform our economic model towards a circular economy approach. Moving towards a circular economy approach is very complex since it requires many changes which must be accompanied by advances in the country's legislation. In Chile, the regulatory framework is making progress on that front.

Everyday more companies are joining this paradigm shift, as they are facing informed consumers who have greater environmental awareness. Adhering to this change is essential for different reasons: non-renewable resources are running out, the planet is filling with garbage and ecosystems are weakening, and most of the production processes we use are highly polluting.

For all of the above reasons, all sectors and stakeholders must get involved in the circular economy approach as it generates environmental, economic and social benefits. This challenge is just beginning, and we must advance in environmental education. One must not overlook the fact that the circular economy is related to the problem of climate change, since it aims to minimize the amount of natural resources that are used to generate products, and the pollutants that are generated during their production and final waste disposal. In this way, this approach manages to reduce the threats of climate change and the degradation of the ecosystems to transit towards a more sustainable planet.

\section{REFERENCES}

[1] Meller, P., 110 años de desarrollo económico chileno, pp. 1880-1990, 2017.

[2] Memoria Chilena, Biblioteca Nacional de Chile. http://www.memoriachilena.gob.cl/ 602/w3-article-752.html. Accessed on: 10 Feb. 2021.

[3] Pinto, J. \& Ortega, L., Expansión minera y desarrollo industrial: un caso de crecimiento asociado, 1850. http://www.memoriachilena.gob.cl/602/w3-article8447.html. Accessed on: 10 Feb. 2021.

[4] Dirección General de Relaciones Económicas Internacionales (DIRECON) \& PROCHILE, Anuario de las Exportaciones Chilenas 2018. https://www.prochile.gob.cl/wp-content/uploads/2018/08/anuario_servicios_ capitulo1_bienes_2018.pdf. Accessed on: 10 Feb. 2021.

[5] Statista, Ranking de los países con mayores reservas de cobre en 2019. https://es.statista.com/estadisticas/635670/reservas-mundiales-de-cobre-por-paises/. Accessed on: 10 Feb. 2021.

[6] Guía minera de Chile, Chile alcanzó una producción récord de 5,8 millones de toneladas de cobre fino durante 2018. https://www.guiaminera.cl/chile-alcanzo-unaproduccion-record-de-58-millones-de-toneladas-de-cobre-fino-durante-2018/\#: :text $=$ Seg $\%$ C3 $\%$ BAn $\% 201 \mathrm{a} \% 20$ fuente $\% 2 \mathrm{C} \% 201 \mathrm{a} \% 20$ producci $\% \mathrm{C} 3 \% \mathrm{~B} 3 \mathrm{n}, \mathrm{de} \% 20$ metal $\%$ 20rojo\%2C\%20para\%20incrementarse. Accessed on: 10 Feb. 2021.

[7] Pearce, D.W. \& Turner, R.K., Economics of Natural Resources and the Environment, JHU Press, 1990.

[8] Su, B., Heshmati, A., Geng, Y. \& Yu, X., A review of the circular economy in China: Moving from rhetoric to implementation. Journal of Cleaner Production, 42, pp. 215-227, 2013.

[9] Ellen Mac Arthur Foundation. https://www.ellenmacarthurfoundation.org/. Accessed on: 13 Feb. 2021.

[10] Bosselmann, K., O Princípio da Sustentabilidade: Transformando Direito e Governança, Revista dos Tribunais: São Paulo, p. 104, 2015. 
[11] Rosa, A.M. \& Ramos, A.L.S., Circular economy, human behavior and law. WIT Transactions on the Built Environment, vol. 179, WIT Press: Southampton and Boston, pp. 35-44, 2018.

[12] Agencia de la ONU para los refugiados (UNHCR-ACNUR) ¿Cuáles son los problemas derivados de la contaminación? https://eacnur.org/blog/. Accessed on: 13 Feb. 2021.

[13] Complejo para Tratamiento de Residuos Urbanos de Zaragoza (CTRUZ), La sutil diferencia entre residuo y basura. https://www.zaragozarecicla.org/. Accessed on: 13 Feb. 2021.

[14] BBC News Mundo, Los 10 países que más y menos basura generan en américa latina (y cómo se sitúan a nivel mundial). https://www.bbc.com/mundo/noticias-45755145. Accessed on: 13 Feb. 2021.

[15] Monasterio, F., Del basurero al vertedero: la ruta de los residuos, 2019. https://www.pauta.cl/calidad-de-vida/del-basurero-al-vertedero-la-ruta-de-losresiduos. Accessed on: 14 Feb. 2021.

[16] Ministerio de medio ambiente (MMA), Economía circular. https://mma.gob.cl/ economia-circular/. Accessed on: 14 Feb. 2021.

[17] Gonzalez, G., Hacia un Chile circular. Presented at 3rd Conferencia UVerde: Economía Circular, Nov. 2020.

[18] Law 20879, Del 25 de noviembre 2015, sanciona el transporte de desechos hacia vertederos clandestinos, ministerio de transporte y telecomunicaciones, gobierno de Chile. https://www.bcn.cl/leychile/navegar?idNorma=1084262. Accessed on: 14 Feb. 2021.

[19] Law 21100, Del 03 Ago. 2018, prohíbe la entrega de bolsas plásticas de comercio en todo el territorio nacional, ministerio del medio ambiente, gobierno de Chile. https://www.bcn.cl/leychile/navegar?idNorma $=1121380 \&$ idParte $=9938442 \& i d V e r s i$ on=2018-08-03. Accessed on: 14 Feb. 2021.

[20] Law 20920, Del 1 Jun. 2016, Establece marco para la gestión de residuos, la responsabilidad extendida del productor y fomento al reciclae, ministerio del medio ambiente, gobierno de Chile. https://www.leychile.cl/navegar?idNorma=1090894. Accessed on: 14 Feb. 2021.

[21] Algramo, https://algramo.com/en/home/. Accessed on: 17 Feb. 2021.

[22] Green Glass, https://www.greenglass.cl/. Accessed on: 17 Feb. 2021.

[23] Cambiaso Hermanos, http://www.cambiaso.cl/. Accessed on: 17 Feb. 2021.

[24] Pesce, M. et al., Circular economy in China: Translating principles into practice. Sustainability, 12(3), pp. 832, 2020. 